\title{
PAMIĘĆ NIEZAKOŃCZONEJ WOJNY. KONFLIKT I KSZTAETOWANIE WSPÓLNOTY ETNOPOLITYCZNEJ W GÓRSKIM KARABACHU
}

\section{The Memory of the Unfinished War: The Conflict and the Shaping of the Ethno-political Community in Nagorno-Karabakh}

The ethno-political conflict and riots in the South Caucasus, followed by the regular Armenian-Azerbaijani war, constitute the most violent episodes during the collapse of the Union of Soviet Socialist Republics. In the light of legal and institutional conditions, the conflict remains open as the Bishkek Protocol signed in May 1994 formally constitutes only a ceasefire. As a consequence of its signing, Nagorno-Karabakh's territory in fact remains an independent state that is not recognised internationally. The permanent state of emergency has a decisive impact on the current relations of Armenia and Azerbaijan, but also on the symbolic and political dynamics of transformations occurring in the ethno-political community in the quasi-state. Using ethnographic material collected during field studies conducted over several years, the article attempts to answer the question of how memorial sites devoted to the conflict shape the ethno-political community of Nagorno-Karabakh. Through the exploratory study of this case, in a broader context,

Artykuł jest efektem badań prowadzonych w Górskim Karabachu w latach 2014-2017. Dotyczy de facto niepodległej, nieuznawanej Republiki Górskiego Karabachu. Obejmuje ona tereny w czasach ZSRS należące do Górsko-Karabachskiego Obwodu Autonomicznego będącego częścią Azerbejdżańskiej Socjalistycznej Republiki Sowieckiej, znajdujące się pod kontrolą Ormian (ok. 92,5 proc.), oraz tereny okupowane siedmiu azerbejdżańskich prowincji będacych pod kontrola Stepanakertu i Erywania. Zob. np.: S. Markedonov, Republika Górskiego Karabachu: kształtowanie się niepodległego państwa, w: Armenia i Górski Karabach $w$ procesach transformacji społecznej $i$ politycznej, red. R. Czachor, Wrocław 2014, s. 128-129. Nazwa zamienna quasi-państwa od 2017 roku jest Republika Arcachu. Nazwy sa równoprawne. W tekście używam nazwy Górski Karabach, chyba że rozmówca użył nazwy „Arcach” bądź występuje ona w przywołanej nazwie. 
I examine the potential of applying the transdisciplinary paradigm of memory research in the analysis of transformations of ethno-political communities in, de facto, independent, non-recognised or partially internationally recognised quasi-states.

Keywords: Nagorno-Karabakh, ethno-political conflict, institutional memory, community, political anthropology.

\section{WSTEP}

Kwestią nieco zaniedbana $\mathrm{w}$ badaniach konfliktów postsowieckich jest analiza endogennych uwarunkowań polityczności pamięci w relacji $z$ kształtowaniem wspólnoty etnopolitycznej bez szerszego geopolitycznego odniesienia ${ }^{1}$. Przedmiotem analizy sa rozważania nad wewnętrzną dynamika procesu i konceptualizacją tożsamości wspólnoty etnopolitycznej w dyskursie, w którym hegemoniczna pozycję przypisuje się samemu konfliktowi i jego reprezentacjom. Obserwacja praktyk pamięci skłania do refleksji nad relacja między komemoracja konfliktu oraz kształtowaniem wspólnoty etnopolitycznej Ormian karabachskich w przestrzeni politycznej quasi-państwa. Konsekwencja tak sprecyzowanego problemu jest pytanie badawcze: jak miejsca pamięci konfliktu kształtuja lokalną wspólnotę? Wspólnota polityczna w najszerszym rozumieniu konstruuje tożsamość i przestrzeń symboliczna na wyobrażeniu o sobie i pamięci wspólnego doświadczenia oraz zdefiniowanej figurze Innego. Kreacja wspólnoty etnopolitycznej Ormian karabachskich opiera się na pamięci o doświadczeniu traumy i walki zakończonej ustanowieniem de facto niepodległego bytu quasi-państwowego. Odwołuje się także do figury Innego - Azerbejdżanina, antagonisty w czasie trwania konfliktu zbrojnego i zawieszonej sytuacji po jego zakończeniu. Zatem, czy możliwa jest konsolidacja wspólnoty bez odniesienia do przeszłości, wykraczająca poza doświadczenie wojny, oraz czy dominująca pamięć konfliktu może zostać zastapiona lub uzupełniona dialogicznymi narracjami pamięci? Hipotetycznie

\footnotetext{
1 Zob.: G.M. Yemelianova, Western academic discourse on the post-Soviet de facto state phenomenon, „Caucasus Survey” 2015, t. 3 (3), s. 226-232. Polski dyskurs akademicki wokół państw de facto niezależnych w znaczacej mierze powiela opisane przez autorkę wzorce.

Skłaniam się ku kategoryzacji konfliktu używanej m.in. przez Emila Souleimanova. Jego esencja sprowadza się do politycznego (w rozumieniu instrumentalnym) wykorzystania różnicy etnicznej. Słuszność tego podejścia potwierdza się zresztą w samej analizie mechanizmu przyczynowego i jego rezultatu w postaci kreacji specyficznej wspólnoty. Zob.: E. Souleimanov, Understanding Ethnopolitical Conflict. Karabakh, South Ossetia, and Abkhazia Wars Reconsidered, New York 2013, s. 13-50.
} 
miejsca pamięci reprezentujące doświadczenie konfliktu maja podstawowe znaczenie dla procesualnego kształtowania wspólnoty wraz z jej przestrzenia symboliczna, fantazmatami oraz sposobami definiowania tożsamości. W badaniu tej relacji zmienną niezależną stanowią wyselekcjonowane przykłady reprezentacji pamięci o konflikcie, podczas gdy zmienna zależna sa mechanizmy i struktury przekształceń $\mathrm{w}$ ramach wspólnoty etnopolitycznej, splecione $z$ narracja tych reprezentacji. Celem artykułu jest kreacja integralnego modelu procesualnego relacji reprezentacji konfliktu $\mathrm{w}$ miejscach pamięci $z$ kształtowaniem się wspólnoty etnopolitycznej w Górskim Karabachu.

Przestrzeń badawcza skupia się również na ogólnym fenomenie kształtowania wspólnot etnopolitycznych, a więc analizowany problem ma szersze znaczenie poznawcze. Wnioski z badań nad Górskim Karabachem i budowana na studium przypadku teoria kształtowania wspólnot etnopolitycznych może służyć do interpretacji modeli pamiętania w innych strefach konfliktu na terenie byłego ZSRS, uwzględniając wewnętrzne uwarunkowania danego quasi-państwa. W perspektywie rozważań nad aspektami symbolicznego znaczenia wojny Górski Karabach jest przykładem konfliktowego i niezamkniętego procesu hegemonicznego ścierania się odmiennych narracji o przeszłości i instrumentalnego wykorzystania i polityzacji w ramach relacji władzy. Artykuł podzielony jest na cztery podstawowe części. We wstępie opisuję zebrany materiał badawczy, kontekst i stan badań oraz metody badawcze. W drugiej przedstawiam historyczny rys sporu o Górski Karabach. W trzeciej, budując teorię, prezentuję wyniki badań terenowych. W czwartej części omawiam główne rezultaty studium w kontekstualnych ramach, analizuję teoretyczna i praktyczna istotność badań oraz przedstawiam perspektywę potencjalnego rozwinięcia.

$\mathrm{W}$ literaturze poruszany jest problem tożsamości w nowej sytuacji politycznej ${ }^{2}$ oraz kwestia nadużycia historii w hegemonicznych próbach budowania narracji instrumentalnej docelowo redefiniujacej wspólnotę w dyskursie politycznym ${ }^{3}$. Istnieje również wiele analiz

\footnotetext{
2 Zob. m.in.: М. Агаджанян, Етнополитическая идентификаиия и причинь Нагорно-Карабахского конфликта, „21-й Век” 2008, t. 1 (7), s. 104-139; V. Kopecek, T. Hoch, V. Baar, Conflict Transformation and Civil Society: The Case of Nagorno-Karabakh, „Europe-Asia Studies” 2016, t. 68 (3), s. 441-459; S. Muth, War, language removal and self-identification in the linguistic landscapes of Nagorno-Karabakh, "Nationalities Papers” 2014, t. 42 (1), s. 63-87; J. O'Loughlin, V. Kolosov, Building identities in post-Soviet „de facto states": cultural and political icons in Nagorno-Karabakh, South Ossetia, Transdniestria, and Abkhazia, „Eurasian Geography and Economics” 2017, t. 58 (6), s. 691-715.

Zob. m.in.: L. Broers, G. Toal, Cartographic Exhibitionism? „Problems of Post-Communism" 2013, t. 60 (3), s. 16-35; V. Cheterian, The Uses and Abuses of History: Genocide
} 
pamięci oraz kolektywnej traumy ${ }^{4}$, a także kwestie historyczne i socjopolityczne w przestrzeni ${ }^{5}$.

Analiza fenomenu Górskiego Karabachu wiąże się z uwarunkowaniami politycznymi w Armenii i Azerbejdżanie. Te odniesienia maja tu znaczenie jedynie kontekstualne. Przedmiotem eksploracyjnego studium przypadku jest Górski Karabach, quasi-państwo i wewnętrzne elementy symboliczne nawiazujace do wojny/konfliktu. Arbitralnie na potrzeby badań określona cezura czasowa to lata 1994-2017. Rok 1994 to moment, gdy zaczęła się kształtować afektywna wspólnota pamięci pokonfliktowej $\mathrm{w}$ stanie wyjątkowym po podpisaniu zawieszenia broni w ramach tzw. protokołu z Biszkeku 5 maja 1994 roku$^{6}$. Ramę czasową zamyka moment ostatniej wizyty terenowej w Górskim Karabachu w roku 2017.

Refleksja oparta jest na wykorzystaniu wielości metod etnograficznych i politologicznych. Podstawowymi danymi, które poddane zostały analizie, sa dokumentacje fotograficzne oraz obserwacje i wywiady

and the Making of the Karabakh Conflict, „Europe-Asia Studies” 2018, t. 70 (6), s. 884-903; O. Geukjian, Ethnicity, Nationalism and Conflict in the South Caucasus: Nagorno-Karabakh and the Legacy of Soviet Nationalities Policy, New York 2016; A. Kasbarian The Geography of Nationalism in Nagorno-Karabakh: Post-Soviet Reality as Post-Colonial Reality, w: After the Soviet Empire: Legacies and Pathways, eds. S. Eliaeson, L. Harutyunyan, L. Titarenko, Leiden 2015; C. Tokluoglu, Definitions of National Identity, Nationalism and Ethnicity in Post-Soviet Azerbaijan in the 1990s, „Ethnic and Racial Studies” 2005, t. 28 (4), s. 722-758; C. Tokluoglu, The Political Discourse of the Azerbaijani Elite on the Nagorno-Karabakh Conflict (1991-2009), „Europe-Asia Studies” 2011, t. 63 (7), s. 1223-1252.

${ }_{4}$ Zob. m.in.: R. Garagazov, Collective Memory in Ethnopolitical Conflicts: The Case of Nagorno-Karabakh, „Central Asia and the Caucasus” 2006, t. 5 (41), s. 145-156; R. Garagazov, Do Woes Unite Foes? Interplay of Narratives, Memory, Emotions and Attitudes in the Karabakh Conflict, „Dynamics of Assymetric Conflict” 2012, t. 5 (2), s. 116-135; R. Garagazov, Painful Collective Memory: Measuring Collective Memory Affect in the Karabakh Conflict. „Peace and Conflict: Journal of Peace Psychology” 2016, t. 22 (1), s. 28-35; R. Garagazov, E. Ismailov, Confrontational Collective Memory in the Caucasus: How Can the "Curse of the Past” Be Overcome? „The Caucasus \& Globalization” 2007, t. 1 (4), s. 101-108; B.A. Шнирельман, Войны памяти. Мифы, идентичность и политика в Закавказе, Москва 2003; V.A. Shnirelman, The Value of the Past: Myths, Identity and Politics in Transcaucasia, Osaka 2001; F. Trupia, Unfreezing the „other": collective trauma and psychological warfare over the Nagorno-Karabakh rivalry, „Journal of Liberty and International Affairs” 2017, t. 2 (3), s. 30-44.

5 Zob. m.in.: P. Adamczewski, Górski Karabach w polityce niepodległego Azerbejdżanu, Warszawa 2012; L. Broers, Recognising politics in unrecognised states: 20 years of enquiry into the de facto states of the South Caucasus, "Caucasus Survey” 2013, t. 1 (1), s. 59-74; T. Hakobyan, Karabakh Diary, Green and Black: Neither War nor Peace, Yerevan 2010; S. Horowitz, Explaining post-Soviet ethnic conflicts: Using regime type to discern the impact and relative importance of objective antecedents, "Nationalities Papers” 2001, t. 29 (4), s. 633-60; M. Kambeck, S. Ghazaryan (eds.), Europe's Next Avoidable War. Nagorno-Karabakh, New York 2013; C. Mutafian, The Karabagh in Twentieth Century, w: Caucasian Knot: The History and Geopolitics of Nagorno-Karabagh, eds. L. Chorbajian, P. Donabedian, C. Mutafian, London 2004.

6 T. de Waal, Black Garden: Armenia and Azerbaijan through Peace and War, New York 2013, s. 250. 
zebrane podczas badań terenowych na Kaukazie Południowym prowadzonych w latach 2013-2017. Jako strategie badawcze wykorzystane zostały etnografia wielomiejscowa oraz triangulacja metod $\mathrm{w}$ ramach jednego badania terenowego, w tym wypadku metoda analizy wizualnej, wywiad pogłębiony i obserwacja częściowo uczestnicząca ${ }^{7}$. Miejsca pamięci (zarówno fizyczne artefakty, jak i miejsca abstrakcyjne), kształtujace symboliczne ramy dyskursu o przeszłości w kontekście kształtowania wspólnoty, zostały wyselekcjonowane na podstawie wywiadów oraz obserwacji częściowo uczestniczącej w zestawieniu $z$ oficjalnymi narracjami polityki pamięci nieuznawanej republiki. Zebrany materiał, w kontekście dyskursu pamięci i wspólnoty, zanalizowany został przy wykorzystaniu jednego $z$ wariantów metody badawczej śledzenia procesu ${ }^{8}$. W ramach praktyki, analiza materiałów zebranych podczas pracy terenowej ma służyć sprawdzeniu potencjału teoretycznego narzędzia do badań relacji pamięci i struktur wspólnoty w konkretnym przypadku oraz w szerszej perspektywie quasi-państw powstałych po rozpadzie ZSRS. Aby tego dokonać, syntetyzowane są zróżnicowane dane konieczne do stworzenia wiarygodnego obrazu wpływu różnych mechanizmów i struktur pamięci na procesualne kształtowanie wspólnoty w Górskim Karabachu. Siła przyczynowa procesu jest przekształcanie emocjonalnej wspólnoty pokonfliktowej opartej na reprezentacjach pamięci, podczas gdy rezultatem - konsolidacja jej określonego modelu w danej sytuacji politycznej permanentnego stanu wyjątkowego.

\section{STAWANIE SIE GÓRSKIEGO KARABACHU. RYS HISTORYCZNY}

Korzenie konfliktu ormiańsko-azerbejdżańskiego sięgają pierwszej połowy XIX stulecia. Zajęcie Kaukazu Południowego przez Imperium Rosyjskie spowodowało masowy exodus muzułmanów (głównie szyitów) zamieszkujących terytorium współczesnego Azerbejdżanu do Persji. Z Persji emigrowali Ormianie, osiedlając się na mieszanych

\footnotetext{
7 Zob. m.in.: M. Banks, Materiały wizualne $w$ badaniach jakościowych, Warszawa 2009, s. 39-44; M. Ciesielska, K. Wolanik Boström, Obserwacja, w: D. Jemielniak (red.), Badania jakościowe. Metody i narzędzia, t. 2, Warszawa 2012, s. 41-68; S. Gudkova, Wywiad $w$ badaniach jakościowych, w: Badania jakościowe..., s. 115-116.

8 D. Breach, R. Brun Pedersen, Process-Tracing Methods. Foundations and Guidelines, Ann Arbor 2013; D. Breach, R. Brun Pedersen, Causal Case Study Methods. Foundations and Guidelines for Comparing, Matching and Tracing, Ann Arbor 2016; D. Collier, Understanding Process Tracing, „Political Science and Politics” 2011, t. 44 (4), s. 823-830.
} 
etnicznie ziemiach Kaukazu Południowego. Zmiany kompozycji etnonarodowej następowały po każdym konflikcie rosyjsko-perskim, stabilizując się pod koniec XIX stulecia. Ormianie na terenie Górskiego Karabachu postrzegani byli jako sprzymierzeńcy Rosjan, podczas gdy Azerbejdżanie traktowani byli przez imperialna władzę jako potencjalny element zagrożenia i sojusznicy Turcji, przede wszystkim ze względu na etnolingwistyczna zbieżność. Boom naftowy nad Morzem Kaspijskim pod koniec XIX stulecia otworzył możliwości wzbogacenia się, $z$ których korzystali głównie Ormianie ze względu na faworyzująca politykę Rosjan. Azerbejdżanie często tracili ziemię w konsekwencji nielegalnego wykupu. $\mathrm{W}$ połączeniu $\mathrm{z}$ tworzacymi się nowoczesnymi wspólnotami etnonarodowymi, kumulowało to napięcia ${ }^{9}$. Napięte relacje między Ormianami i Azerbejdżanami doprowadziły do regularnej wojny w 1905 roku. Doszło do pogromów i walk, początkowo w Baku, Nachiczewanie i Erywaniu, a następnie na terenie Górskiego Karabachu. Szczególnie intensywne były starcia w Szuszi (orm. Gnızh, azer. Şuşa). Wojna, zwana w źródłach rosyjskich ormiańsko-tatarska, zdaniem Tadeusza Świętochowskiego stanowiła podstawę konsolidacji tworzącej się tożsamości azerbejdżańskiej ${ }^{10}$. Rewolucja Październikowa spowodowała utworzenie krótko istniejaccej Republiki Transkaukaskiej. Rozpad republiki po trzech miesiącach i wycofanie się zarówno Rosjan, jak i Turków $z$ Górskiego Karabachu, a także decyzja władz brytyjskich o przyznaniu tych ziem Azerbejdżanowi, spowodowały wybuch wojny partyzanckiej i kolejne starcia ormiańsko-azerbejdżańskie. Szuszi było świadkiem krwawej rzezi w marcu 1920 roku, gdy Azerbejdżanie zmasakrowali Ormian, niszcząc ormiański kwartał ${ }^{11}$. Wkrótce, zarówno Azerbejdżan z Górskim Karabachem, jak i Armenia zostały zaanektowane przez Rosję Sowiecka. Nastapiła sowietyzacja Kaukazu Południowego mająca wpływ na sytuację w Górskim Karabachu. Po serii pertraktacji w ramach bolszewickiego Biura Kaukaskiego w sierpniu 1923 roku utworzono Nagorno-Karabachski Obwód Autonomiczny w ramach Azerbejdżanu ${ }^{12}$. Decyzja bolszewików nie zlikwidowała jednak problemu, a jedynie uśpiła go na kilkadziesiąt lat.

9 S.E. Cornell, Small Nations and Great Powers. A Study of Ethnopolitical Conflict in the Caucasus, London 2001, s. 53-55.

10 T. Świętochowski, Russian Azerbaijan, 1905-1920: The Shaping of a National Identity in a Muslim Community, Cambridge 1985, s. 37-63.

11 R. Hovannisian, The Republic of Armenia, w: The Armenian People from Ancient to Modern Times. Foreign Dominion to Statehood: The Fifteenth Century to the Twentieth Century, ed. R. Hovannisian, t. II, New York 1997, s. 303-346.

12 A. Saparov, Why Autonomy? The Making of Nagorno-Karabakh Autonomous Region 1918-1925, „Europe-Asia Studies” 2012, t. 64 (2), s. 313-317. 
Poczatek pieriestrojki oraz powolna destrukcja ZSRS doprowadziły do wznowienia dyskusji nad statusem Górskiego Karabachu. W połowie lat osiemdziesiatych na fali liberalizacji Ormianie stworzyli Ruch Karabachski, którego celem było przyłączenie obwodu do Armeńskiej SRS. Ruch szybko przerodził się w zaczątki ormiańskiego społeczeństwa obywatelskiego oraz wzmocnił nacjonalistyczne antysowieckie dążenia Ormian ${ }^{13}$. Odmowa Moskwy uznania pretensji Ormian poskutkowała wzrostem napięć etnicznych w Armenii i Azerbejdżanie. W lutym 1988 roku w Sumgaicie, niedaleko Baku, w wyniku pogromu zginęło kilkudziesięciu Ormian. W rezultacie rozpoczęły się dwustronne ataki, między innymi w karabachskim Askeranie, a następnie deportacje Azerbejdżan z Armenii i Ormian z Azerbejdżanu. Mimo prób interwencji ze strony władz sowieckich, nie udało się już powstrzymać intensyfikacji działań i eskalacji konfliktu wokół Górskiego Karabachu. Według danych $z$ ostatniego spisu z 1989 roku obwód autonomiczny zamieszkiwało 76,9 proc. Ormian oraz 21,5 proc. Azerbejdżan ${ }^{14}$. Trudno wskazać jednoznacznie, kiedy rozpoczą się konflikt. Od roku 1988 w Armeńskiej i Azerbejdżańskiej SRS dochodziło do napięć etnopolitycznych ${ }^{15}$. Armenia (przez parlament) zadeklarowała niepodległość w sierpniu 1990 roku, Azerbejdżan - w sierpniu 1991 roku. Po referendum niepodległościowym w styczniu 1992 roku ogłoszono niepodległość Górskiego Karabachu. Eskalacja konfliktu przypada na lata 1991-1993 ${ }^{16}$. W maju 1994 roku doszło do podpisania bezterminowego zawieszenia broni. Od tego czasu Górski Karabach istnieje w stanie wyjatkowym - de facto jest nieuznawanym, niepodległym państwem, de iure pozostaje częścią Azerbejdżanu. Od 1994 linia frontu regularnie jest miejscem eskalacji sporu (jak w kwietniu 2016 roku). Rozmowy o potencjalnym rozwiąaniu konfliktu tocza się m.in. w ramach tzw. Grupy Mińskiej Organizacji Bezpieczeństwa i Współpracy w Europie.

13 L. Abrahamian, Civil Society Born in the Square: The Karabagh Movement in Perspective, w: The Making of Nagorno-Karabakh. From Secession to Republic, ed. L. Chorbajian, New York 2001, s. 116-134; P. Rutland, Democracy and Nationalism in Armenia, „Europe-Asia Studies" 1994, t. 46 (5), s. 839-861.

14 R.H. Rowland, Population Trends in a Contested Pseudo-State: The Case of Nagorno-Karabakh, „Eurasian Geography and Economics” 2013, t. 49 (1), s. 99-111.

15 T. de Waal, Black Garden..., s. 108-138.

16 Wskazanie rzeczywistego momentu, kiedy wybucha wojna, jest skomplikowane i dyskusyjne. Przyjmuję za De Waalem: druga połowa 1991 roku, faktycznie przeniosła konflikt na poziom międzypaństwowy (mimo że zarówno Armenia, jak i Azerbejdżan zostały uznane dopiero w 1992 roku przez społeczność międzynarodowa). Zob.: T. de Waal, Black Garden..., s. 172-175. 


\section{ANALIZA}

\section{DEFINIOWANIE WSPÓLNOTY A PAMIECĆ INDYWIDUALNA}

W ujęciu Ferdinanda Tönniesa, wspólnota opiera się na woli organicznej, emocjonalnych odniesieniach, pozytywnym stosunku i identycznych wartościach ${ }^{17}$. Takim społecznościom wewnętrznie przypisywana jest wiecznotrwałość i esencjalny charakter. Zatem, wspólnota jest afektywnym konstruktem, skonsolidowanym wokół abstrakcyjnych idei, a bycie jej częścia potwierdzane jest przez współdzielone doświadczenie kulturowe oraz postrzeganie jej istoty za daną. Ideologiczne narracje o etnogenezie, mające potwierdzać odwieczność przynależności Górskiego Karabachu, oparte sa na emocjonalnych połaczeniach zawartych w symbolice upamiętnienia konfliktu.

Afektywna więź manifestuje się w sposobach celebracji indywidualnych miejsc pamięci i jednostkowych narracjach o konflikcie, czego przykładem sa cmentarze, takie jak nekropolia pod monastyrem Gandzasar (orm. quúăuuunh цuúp - Gandzasari Vank). Podzielony jest on na dwie części. Bliżej klasztoru znajdują się pozostałości średniowiecznego cmentarza. Dalej jest ten współczesny, część nagrobków pochodzi z czasów sowieckich, większość datowana jest na lata 1991-1994. Przeważaja nagrobki młodych mężczyzn. Częstym motywem jest ukazanie postaci w mundurze i $z$ bronia. Gromadza się tu grupy kobiet ubranych na czarno, siedzacych przy grobach. W plastykowych reklamówkach przynoszą jedzenie oraz wódkę. Jedzeniem trzeba się podzielić $z$ potrzebującymi oraz $z$ innymi kobietami, które przychodzą wspominać poległych ${ }^{18}$. Mówią: „przychodzimy wspominać synów poległych za Arcach". Pamięć pielęgnowana jest w codziennych opowieściach i w uczestnictwie $\mathrm{w}$ rocznicowych wydarzeniach ${ }^{19}$. Struktura pamięci, będąca manifestacją tego pierwszego mnemonicznego elementu mechanizmu przyczynowego, oparta jest na wspólnym doświadczeniu straty. W narracjach, poza warstwą oczywistego smutku, często pojawia się przeświadczenie, że ofiara została poniesiona słusznie, a dzięki niej Górski Karabach może istnieć. Oznacza to rozsze-

17 Zob.: F. Tönnies, Wspólnota $i$ stowarzyszenie: rozprawa o komunizmie $i$ socjalizmie, Warszawa 1988, s. 21-23.

18 Szczególny kolektywny charakter maja upamiętnienia odbywające się 7 stycznia, dzień po Bożym Narodzeniu, w ormiańskie święto merrelots - dzień odwiedzania martwych (orm. Utinting).

19 Na podstawie wywiadów i obserwacji z badań terenowych prowadzonych w Górskim Karabachu. 
rzenie wyłącznie emocjonalnego pamiętania o element wartościujący i celowy. Pozwala to utrwalać tożsamość, w której pamięć o konflikcie jest podstawa wspólnotowości ${ }^{20}$. Jej recepcja na poziomie społecznym spleciona $z$ instrumentalizacja polityczna wpływa następnie na jej przekształcanie $^{21}$.

\section{INSTYTUCJONALNA POLITYKA TWORZENIA MIEJSC PAMIECI}

Niezwykle ważnym elementem konsolidującym wspólnoty etniczne jest utożsamienie w opozycji do Innego. To, kim się nie jest, na poziomie tożsamości jest istotniejsze od tego, kim się jest ${ }^{22}$. Wspólnota etnopolityczna oparta na konflikcie istnieje w stanie przejścia, podlegajac ciagłym reinterpretacjom. Ich celem jest osiagnięcie wymiernego efektu politycznego. Odwołując się do Victora Turnera, można stwierdzić, że kształtowana przez politykę pamięci wspólnota w Górskim Karabachu ma formę pewnej normatywnej communitas. Pierwotnie jest ona wyłącznie afektywna, egzystencjalna i aksjologiczna, z czasem sama kreuje potrzebę przekształcenia w trwalszy system społecz$n y^{23}$. Jej hybrydalna forma wynika $z$ zawieszenia pomiędzy byciem organiczna wspólnotą a modernistyczna forma. Przez polityczna instrumentalizację i normatywizację przekształca się w liminalny byt, nie konsolidując sie jednak w pełni jako nowoczesny model stowarzyszenia. Najważniejszym aspektem instrumentalizacji polityki tożsamości, która służy umacnianiu niedookreślonej wspólnoty, jest oficjalna pamięć i jej miejsca. Konieczne jest istnienie sieci symbolicznej pokonfliktowej wspólnoty, która wpisuje się w nowe etnopolityczne

20 Ten wniosek potwierdzaja m.in. badania organizacji International Alert. Zob.: L. Sotieva, A. Inal-Ipa, J. Javakhishvili, L. Kvarchelia, Envisioning Peace. An Analysis of Grassroots Views on Nagorny Karabakh Conflict, „International Alert” 2018, URL: http://www. epnk.org/sites/default/files/page-files/Caucasus_EnvisioningPeace_EN_2018.pdf [dostęp: 11 marca 2019].

21 Zob.: V.A. Shnirelman, The Value of the Past..., s. 33-258.

22 Ilham Abbasov i Sergey Rumyantsev na podstawie azerbejdżańskich podręczników opisali kreacje wspólnoty w opozycji do figury „historycznego wroga”. Zob.: I. Abbasov, S. Rumyantsev, Ways to Perpetuate the Past: Analyzing the Images of "Others" in Azerbaijani History Textbooks, w: Contemporary History Textbooks in the South Caucasus, ed. L. Veselý, Prague 2008, s. 33-56; S. Rumyantsev, The Karabakh Conflict and the Image of he „Historical Enemy” in Azerbaijani Textbooks, „Caucasus Analytical Digest” 2016, nr 84, s. 18-22. Jest ona obecna również w ormiańskich podręcznikach, o czym pisali Mikayel Zolyan oraz Tigran Zakaryan. Zob.: M. Zolyan, T. Zakaryan, The Images of "Self” and „Other" in Textbooks on History in Armenia, w: Contemporary History Textbooks..., s. 11-32.

23 Liminalności używam tutaj w znaczeniu bycia „pomiędzy”, w stanie przejściowym, często rytualnym, pomiędzy dwoma fazami. Zob.: V. Turner, The Ritual Process: Structure and Anti-Structure, New York 1995, s. 94-131. 
uwarunkowania. Konflikt staje się rytuałem przejścia, strukturyzując antagonistyczna wizję wspólnoty w celu normatywizacji docelowo suwerennej władzy w permanentnym stanie wyjątkowym.

Miejscem pamięci, w którym ten proces się manifestuje, jest Państwowe Muzeum Historyczne i Krajoznawcze Arcachu (orm. Ungupup

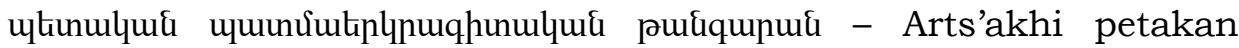
patmayerkragitakan t'angaran; ros. Арцахский государственный историко-краеведческий музей). Zgodnie $z$ informacja na tablicy przy wejściu, zostało ono założone w 1939 roku, wbrew dyskryminującej Ormian polityce Azerbejdżańskiej SRS. Dzięki wytrwałości udało się zebrać w nim kolekcję dokumentującą historię Górskiego Karaba$\mathrm{chu}^{24}$. Połączenie historii i etnografii lokalnej z szerszym kontekstem historycznym i geopolitycznym jest oficjalna reprezentacja przeszłości. Nie ma tu miejsca na wspomnienie wielokulturowego charakteru Górskiego Karabachu. Ekspozycja wskazuje, że autochtonicznymi mieszkańcami Górskiego Karabachu sa Ormianie, a azerbejdżańska historia regionu postrzegana jest jako tymczasowa okupacja. Przekształcanie wspólnoty i płynny charakter wymagaja jednowymiarowej manifestacji. Symboliczne znaczenie ma mapa zestawiajaca ofiary Ludobójstwa Ormian z 1915 roku z ofiarami pogromu w Sumgaicie z 1988 roku $^{25}$. Czarna Turcja i czarny „turkijski” ${ }^{26}$ Azerbejdżan z trupimi czaszkami i skrzyżowanymi piszczelami, a pośrodku czerwona Armenia spływająca krwią. Jest to potwierdzenie schematu wartości, w którym budowana jest ciagłość tożsamości Ormian od figury ofiary Ludobójstwa do konieczności obrony przed kolejna masakra w wojnie karabachskiej. W tej interpretacji następuje ujednolicenie zewnętrznego wroga zagrażającego nie tylko ormiańskiej państwowej niezależności, ale także fizycznej i kulturowej egzystencji27. Karabachski model postrzegania Azerbejdżan jako kontynuatorów młodotureckiej

${ }^{24} \mathrm{~W}$ oficjalnych elementach ekspozycji oraz na podstawie rozmów $\mathrm{z}$ opiekunami nie da się stwierdzić, czy ekspozycja została znacząco zmieniona po zakończeniu wojny, wcześniej reprezentując wyważoną, dwustronną wersję historii regionu.

25 Pogrom ormiańskiej ludności w industrialnym mieście Sumgait koło Baku. Faktyczny przebieg wydarzeń został współcześnie zmieszany z propagandowymi wersjami narracji ormiańskiej i azerbejdżańskiej oraz narastającą wokół tych wydarzeń mitologią. Zrównoważony opis wydarzeń przedstawia De Waal. Zob. T. de Waal, Black Garden..., s. 30-45.

${ }^{26}$ W Armenii słowo często używane do określenia Azerbejdżan to Turek (ros. Tюрк Tiurk), literalnie oznaczające członka turkijskiej (tureckiej) wspólnoty etnojęzykowej. Użycie tego określenia ma pejoratywny kontekst wynikający z pozbawiania Azerbejdżan prawa do oddzielnej tożsamości.

27 Harutyun Marutyan twierdzi, że kwestia Górskiego Karabachu w ormiańskim dyskursie o pamięci istnieje jako logiczne przedłużenie podstawy ormiańskiej tożsamości, a więc zagadnienia Ludobójstwa. Na podstawie wywiadu przeprowadzonego w Erywaniu 6 sierpnia 2014 roku. 
polityki anihilacji ${ }^{28}$ jest wyraźnie podkreślony przez dalszą część ekspozycji. Wojna to moment, kiedy opór był konieczny, aby zapewnić przetrwanie narodu przed próba jego likwidacji. Mechanizm ciagłości wygląda następująco: strata Górskiego Karabachu oznaczałaby zniknięcie Armenii, a potem Ormianie w diasporze w ciagu trzech generacji rozmyliby się jako naród w procesie asymilacji kulturowej. Zatem, zwycięstwo w wojnie karabachskiej transgresyjnie pozwoliło zamienić tożsamość ofiar Ludobójstwa w tożsamość zwycięzców ${ }^{29}$.

Uzupełnieniem oficjalnej narracji sa analogiczne sposoby celebrowania najważniejszych rocznic państwowych - Dnia Republiki Arcachu (Dzień Niepodległości) (orm. Unguup <uunuulinnıрjuu on - Arts'akhi Hanrapetut'yan or) (2 września) oraz Dnia Arcachskiej Armii Obronnej

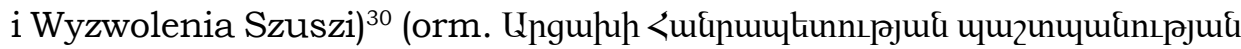
puifulh ti Gnı2hh uquunuqnuiud on - Arts'akhi Hanrapetut'yan pashtpanut'yan banaki yev Shushii azatagrman or) (9 maja). W Stepanakercie odbywają się marsze, podczas których niesione sa flagi Górskiego Karabachu, uczestnicy wkładaja koszulki w kolorach ormiańskiej i karabachskiej flagi ${ }^{31}$. Głównym punktem obchodów sa wizyty polityków z Armenii. Podczas oficjalnych wystapień władz ormiańskich i karabachskich, w formie powtarzającego się rytuału, przedstawiana jest polityczna wizja przekształcania wspólnoty, zbieżna $z$ endogennym procesem tożsamościowym w Górskim Karabachu oraz polityką Erywania wobec negocjacji międzynarodowych o statusie nieuznawanej republiki. Podkreślana jest więc jedność Armenii i Górskiego Karabachu (ideologia miatsum) oraz formułowany postulat, że w rozmowach o zmianach muszą uczestniczyć politycy reprezentujący nieuznawane państwo. Jest to kluczowe dla ormiańskiej pozycji, a więc odwołania do samostanowienia narodów jako zasady prawa międzynarodowego ${ }^{32}$.

28 Partia młodoturecka przejęła władzę w Imperium Osmańskim w 1908 roku. Główni politycy tego ugrupowania (m.in. Talaat Pasza i Enwer Pasza byli odpowiedzialni za przygotowanie i przeprowadzenie Ludobójstwa Ormian w 1915 roku.

29 Na podstawie wywiadów przeprowadzonych w latach 2014-2017 z ormiańskimi ekspertami i politykami. W tej kwestii wypowiadali się m.in. Harutyun Marutyan (6 sierpnia 2014), czy Levon Shirinyan (12 sierpnia 2014).

${ }_{30}$ Po zajęciu Szuszi Ormianie zabezpieczyli korytarz laczyński łączący Armenię z Górskim Karabachem oraz zakończyli oblężenie Stepanakertu i rozpoczęli ofensywę. Zob. T. Hakobyan, Karabakh Diary..., s. 128-131.

31 Pomarańcz oznacza kolor Wyżyny Armeńskiej, czerwień - krew Ormian przelana za Armenię, a błękit kolor nieba nad Armenią. Karabachska flaga w kolorystyce jest identyczna, elementem dodanym jest biała trójkątna ścieżka oznaczająca aktualne oddzielenie Górskiego Karabachu od Armenii i nadzieję na ponowne zjednoczenie. Ma ona również nawiazywać do tradycyjnego wzoru używanego na dywanach pochodzacych z Górskiego Karabachu.

32 Tę narracje zastosował w maju 2018 Nikol Pashinyan. Zob. А. Григорян, Пашинян принял участие в торжествах по случаю Дня Победы в Степанакерте, „Кавказкий 
W zamyśle manifestowana jest tymczasowość obecnej wspólnoty. Każda zmiana zewnętrzna (w Armenii lub w efekcie eskalacji konfliktu) musi szybko spowodować całkowite przekształcenie hegemonicznego modelu wspólnoty. Zmiana musi nastapić, kiedy Górski Karabach zjednoczy się z Armenia lub zostanie międzynarodowo uznany. Jednak specyfika konfliktu oraz permanentnego stanu wyjątkowego, zamkniętych w trwaniu quasi-państwa, sprawia, że nie istnieja teraz żadne uwarunkowania pozwalające sankcjonować tę tymczasowość, która oznaczałaby potencjalne zakończenie zawieszenia. Stan wyjattkowy $z$ definicji ma charakter tymczasowy, jednakże w Górskim Karabachu jego pożądana wersja zdaje się być ta, opierająca się na bezterminowości.

\section{INTERAKCJA SPOŁECZNA I SPRZEŻENIE ZWROTNE}

Elementem mechanizmu przyczynowego, który wynika $z$ bezterminowości, jest splatanie oficjalnej narracji o konflikcie $z$ indywidualnymi wspomnieniami w sprzężeniach zwrotnych. Wspólnota wiąże się przez interakcję społeczną i polityczną oraz sens nadawany tej interakcji przez konkretną sieć symboli. Zewnętrznie natomiast określana jest przez egzogenne próby manipulacji i kontroli nad reprezentacjami wspólnotowej tożsamości ${ }^{33}$. Poziom pierwotnej wspólnoty splata się $z$ polityczna instrumentalizacja przez odniesienie do figury Innego i wewnętrzne przekształcenia. Zaciera się granica pomiędzy utrzymywaniem wspólnego sensu w kolektywnej pamięci a instrumentalnie budowaną i politycznie normatywizowaną pamięcią oficjalną. Utrwala się narracja styku, która stanowi podstawę wspólnoty stanu zawieszonego.

Przykładem instytucjonalizacji indywidualnej pamięci jest $\mathrm{Mu}-$ zeum Poległych Żołnierzy (orm. 2nhluð uquunuúununhuliknh hh2uunulh pulqqunui - Zohvats azatamartikneri hishataki t'angaran) ${ }^{34}$. Inicjatorka jego stworzenia jest Gayla Arustamyan, matka żołnierza, który poległ w czasie wojny w wieku 21 lat. Gayla zebrała zdjęcia 3250

Узел" 2018, https://www.kavkaz-uzel.eu/articles/320258/ [dostęp: 11 marca 2019]. Na sposób prezentowania tego zagadnienia w kontekście prezydenta Levona Ter-Petrosyana, zwrócił uwagę Mikayel Hovhannisyan. Zob.: M. Hovhannisyan, The Use of Images of the External Friend and Enemy in Armenian Domestic Political Discourse: An Analysis of Speeches given by the First President Levon Ter-Petrosyan (September 2007 - May 2011), w: J. Javakhishvili, L. Kvarchelia (eds.), Myths and Conflict in the South Caucasus. Instrumentalization of Conflict in Political Discourse, t. 2, „International Alert” 2013, URL: https:/ /www.international-alert.org/sites/default/files/publications/Caucasus_2013_Myths_Vol2_EN.pdf, s. 74 [dostęp: 11 marca 2019].

${ }_{33}$ J.C. Walsh, S. High, Rethinking the Concept of Community, „Histoire sociale/Social History" 1999, t. 32 (64), s. 272-273.

${ }_{34}$ W ormiańskiej nazwie muzeum znaleźć można słowo azatamartikneri. Oznacza ono bojownika wolności. 
karabachskich żołnierzy, którzy zginęli, a także 132, którzy zaginęli. Jest to przykład intymnego wspomnienia matki, która przez emocjonalne zapotrzebowanie przyczyniła się do instytucjonalizacji afektywnej wspólnoty. W zamyśle miało to pomóc rodzinom doświadczonym przez stratę. Kolektywność tego aktu oparta jest więc na wspólnym i emocjonalnym powiazaniu doświadczonych tą sama trauma ${ }^{35}$. Przez społeczna interakcję muzeum nabiera jeszcze jednego wymiaru symbolicznego. To, co dotychczas celebrowane było w formie tradycyjnego odosobnionego aktu, pozbawionego politycznego ukontekstowienia, a więc ból i strata, w normatywizowanej formie muzeum nabiera etnopolitycznego charakteru. Zaczyna ono spełniać edukacyjna i ideologiczna funkcję. Jego przekaz jest jednoznaczny: wojna karabachska została wygrana, bo byliśmy w stanie się zjednoczyć jako Ormianie. W tej narracji brak wspólnoty, zwłaszcza w obliczu wyobrażonego zagrożenia ze strony dyskursywnego wroga, będzie oznaczać ponowną stratę Górskiego Karabachu, a w konsekwencji anihilację Ormian, gdyż taki jest cel wyobrażonego antagonisty.

Innymi przykładami splatania porządków są czołgi upamiętniające dwie ważne bitwy - o Szuszi, zakończoną w maju 1992 roku, oraz o Agdam w czerwcu i lipcu 1993 roku (fot. 1 i 2).

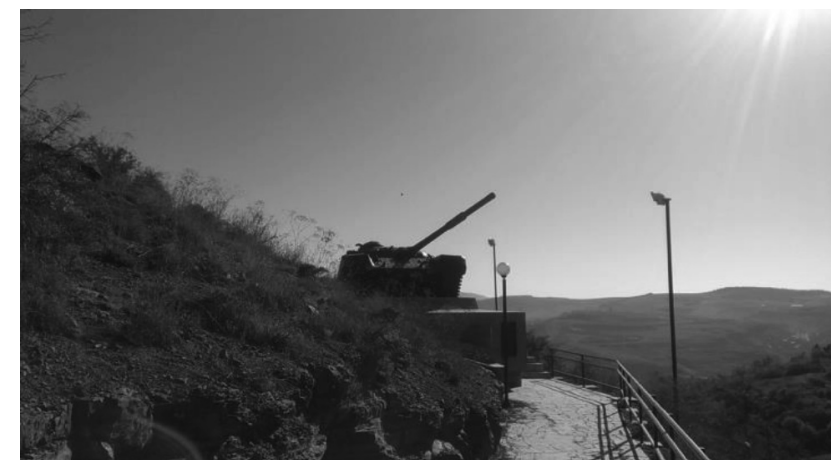

Fot. 1. Czołg Gagika Avsharyana ${ }^{36}$. W dole Stepanakert

(B) B. Krzysztan

35 Opis muzeum oraz wywiad z Gaylą można znaleźć w artykule Nanore Barsoumian. Źródło to trzeba traktować $z$ pewnym dystansem ze względu na propagandowy charakter publikowanych tam materiałów. Zob.: N. Barsoumian, In the Name of Her Son: The Story Behind Artsakh's Museum of Fallen Soldiers, „Armenian Weekly” 2013, URL: https://armenianweekly.com/2013/08/31/in-the-name-of-her-son-the-story-behind-artsakhs-museum-of-fallen-soldiers/ [dostęp: 11 marca 2019].

36 Gagik Avsharyan był dowódca czołgu przekształconego w memoriał. Bohaterstwo jego samego i całej załogi, sprowadzone do opowieści o samotnej potyczce z azerbejdżańskimi obrońcami Szuszi, stanowi jedna z najważniejszych narracyjnych relacji pamięci o wojnie. Zob.: T. de Waal, Black Garden..., s. 196-198. 


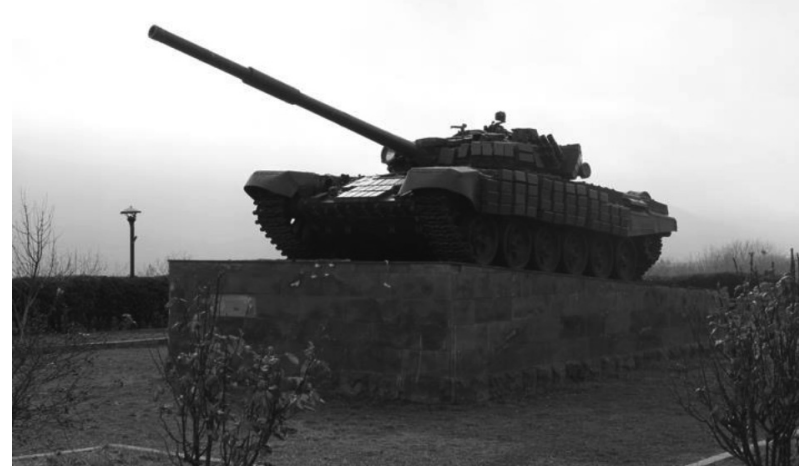

Fot. 2. Czołg upamiętniający bitwę o Agdam (R) B. Krzysztan

Manifestacje zawieraja elementy wspomnienia indywidualnego (niedaleko obu czołgów umieszczone sa groby poległych w czasie bitew żołnierzy) oraz instrumentalny przekaz polityczny. Łącząc indywidualne wspomnienie czasu wojny $z$ mitem heroiczności karabachskich ochotników, oba upamiętnienia odwołują się do minionej przeszłości, manifestując ormiańskie poświęcenie w celu wyzwolenia Szuszi i całego Górskiego Karabachu. Komemoracja prostego żołnierza przestaje mieć charakter intymnego spotkania najbliższych, ale staje się doświadczeniem wspólnoty. Umieszczenie w sasiedztwie grobów memoriału instrumentalizuje miejsca pamięci i nadaje im wymiar ideologiczny. Czołg nie jest jedynie wspomnieniem minionego, ale również spaja procesualna i wyimaginowana pokonfliktowa wspólnotę. Przez zlewanie się elementów indywidualnej pamięci $z$ oficjalnymi miejscami upamiętnień wspólnota zwrotnie eksploruje fantazmaty, które przenoszone sa $z$ poziomu ideologicznego wyobrażenia na poziom pojmowania ich jako realnych danych.

\section{REDEFINICJA POKONFLIKTOWEJ WSPÓLNOTY}

Konflikt jest jednak również przeszkodą na drodze do pełnej konsolidacji wspólnoty w permanentnym stanie wyjątkowym. Giorgio Agamben zwraca uwagę na problem $z$ precyzyjna definicją. Postrzeganie stanu wyjatkowego upraszczane jest przez sprowadzenie jego charakteru do rzymskiej sentencji necessitas non habet legem (konieczność nie zna prawa). Nie jest to jednak wystarczajace, gdyż istotny jest również fakt polityczny. Pozwala on na wprowadzenie stanu wyjątkowego wów- 
czas, kiedy nie istnieje rzeczywista konieczność. Stan wyjątkowy jest brakiem balansu między prawem publicznym i faktem politycznym na wieloznacznym pograniczu prawa i polityki ${ }^{37}$. Uzasadnione jest więc jego teoretyczne użycie w kontekście egzystencji zawieszonych konfliktów, państw istniejących de facto i ich niejednoznacznych wspólnot. Równie ważnym aspektem stanu wyjątkowego jest jego relacja $z$ suwerennościa. Carl Schmitt twierdził, że „ten, kto decyduje o stanie wyjatkowym, jest suwerenny"38. Kto zatem decyduje o stanie wyjatkowym, decyduje w Górskim Karabachu. Biorąc pod uwagę oczekiwanie utrzymania status quo przez suwerenne władze poza Górskim Karabachem, na tym etapie wnioskować można, że ta decyzja jest poza jurysdykcja władz w Stepanakercie oraz demokratycznymi instytucjami, które powinny dawać taka możliwość bezpośrednio dotkniętym codzienna egzystencja w permanentnym stanie wyjątkowym.

Elementem wspólnotowości jest pozycja człowieka wobec stanu wyjatkowego i jego relacja $z$ byciem na ziemi niczyjej, zawieszonej pomiędzy prawem i faktem politycznym ${ }^{39}$. Trwanie realizuje się $\mathrm{w}$ strukturach pamięci zawartych w narracjach indywidualnych, oficjalnych i hybrydalnych, utrwalających przeświadczenie o wyjątkowości wspólnoty. Całość egzystencji uwarunkowana jest przez konflikt - przez wspomnienia, reprezentacje oraz konieczność bycia uczestnikiem przesileń, życia na linii frontu i możliwości wybuchu wojny na pełna skalę $^{40}$. Stan wyjątkowy jest rezultatem mnemonicznych i wyobrażonych figur danej wspólnoty, jednocześnie kształtując ją wedle reguł pozbawionych zróżnicowanych ideologii i procedur. Instrumentalizacja przeszłości w polityce jest jednowymiarowa - istnieje wyłacznie jeden porzadek interpretacji, który kształtuje się przez interakcje pomiędzy indywidualnym poziomem pamiętania oraz normatywizowanym oficjalnym poziomem polityki pamięci.

Przykładem takiego utrwalania wspólnoty jest pomnik „Jesteśmy

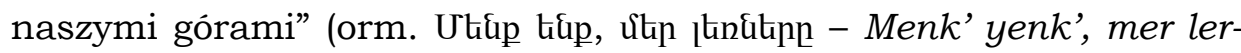
mery) (fot. 3). Nie stanowi on bezpośredniego nawiazania do wojny, ale zmiana jego warstwy znaczeniowej po zakończeniu konfliktu jest ważna dla obrazu wspólnoty.

37 G. Agamben, State of Exception, Chicago 2005, s. 1.

38 C. Schmitt, Teologia polityczna $i$ inne pisma, Kraków 2000, s. 33.

39 G. Agamben, State..., s. 1-2.

40 Na podstawie wywiadów z mieszkańcami Stepanakertu, Szuszi i Wanku. Wartościowym źródłem jest też projekt Unheard Voices. Zob.: Unheard Voices Overview, 2015, URL: http://www.epnk.org/sites/default/files/page-files/Unheard\%20voices\%20ENGLISH\%20 LINKS.pdf [dostęp: 11 marca 2019]. 


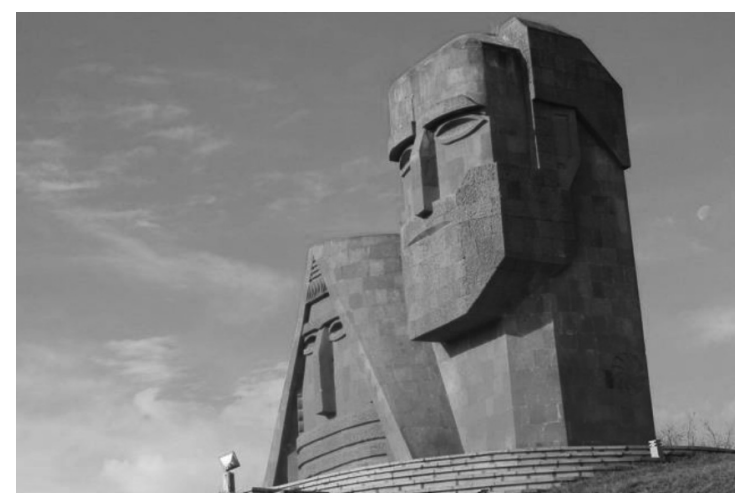

Fot. 3. Pomnik „Jesteśmy naszymi górami” (Tatik i Papik)

(B) B. Krzysztan

Monument przedstawia dwoje starszych ludzi. Zgodnie $z$ lokalnym mitem, mieszkańcy Górskiego Karabachu znani są z długowieczności, a sama republika $z$ najwyższego odsetka osób przekraczających setny rok życia w całym byłym ZSRS. Hołd złożony długowieczności, szybko zmienił swoją symbolikę, stając się reprezentacja etnopolityczną Ormian. Jak pisze John Antranig Kasparian. Nazwa „Jesteśmy naszymi górami" wskazuje na narracyjne połączenie zagadnienia narodu (wspólnoty Ormian karabachskich) oraz natury ${ }^{41}$. Celem takiej manifestacji jest podkreślenie relacji historii i geografii Górskiego Karabachu oraz wspólnoty. Ormian karabachskich nie da się oddzielić od Górskiego Karabachu, zniszczenie wspólnoty Ormian oznaczałoby zniszczenie Górskiego Karabachu jako takiego. Konflikt jest nie tylko o tożsamość, ale i historyczne wyobrażenie ${ }^{42}$. Wspólnota zbudowana $\mathrm{w}$ permanentnym stanie wyjatkowym trwa w ciagłej świadomości tego sporu.

\section{WNIOSKI. WSPÓLNOTA, KTÓRA NADCHODZI}

Niestabilność stanu wyjątkowego sprawia, że konsolidacja wspólnoty w nieuznawanym państwie nie może mieć miejsca. Nie może w konsekwencji nastapić całkowite przejście od wspólnotowej formy etnopolitycznej do stowarzyszeniowej, przykładowo w postaci modernistycznie

41 J.A. Kasparian, „We Are Our Mountains”. Nation as Nature in the Armenian Struggle for Self-Determination, Nagorno-Karabagh, w: The Making of Nagorno-Karabagh. From Secession to Republic, ed. L. Chorbajian, New York 2001, s. 138-141.

42 R. Garagazov, Do Woes Unite..., s. 118-119. 


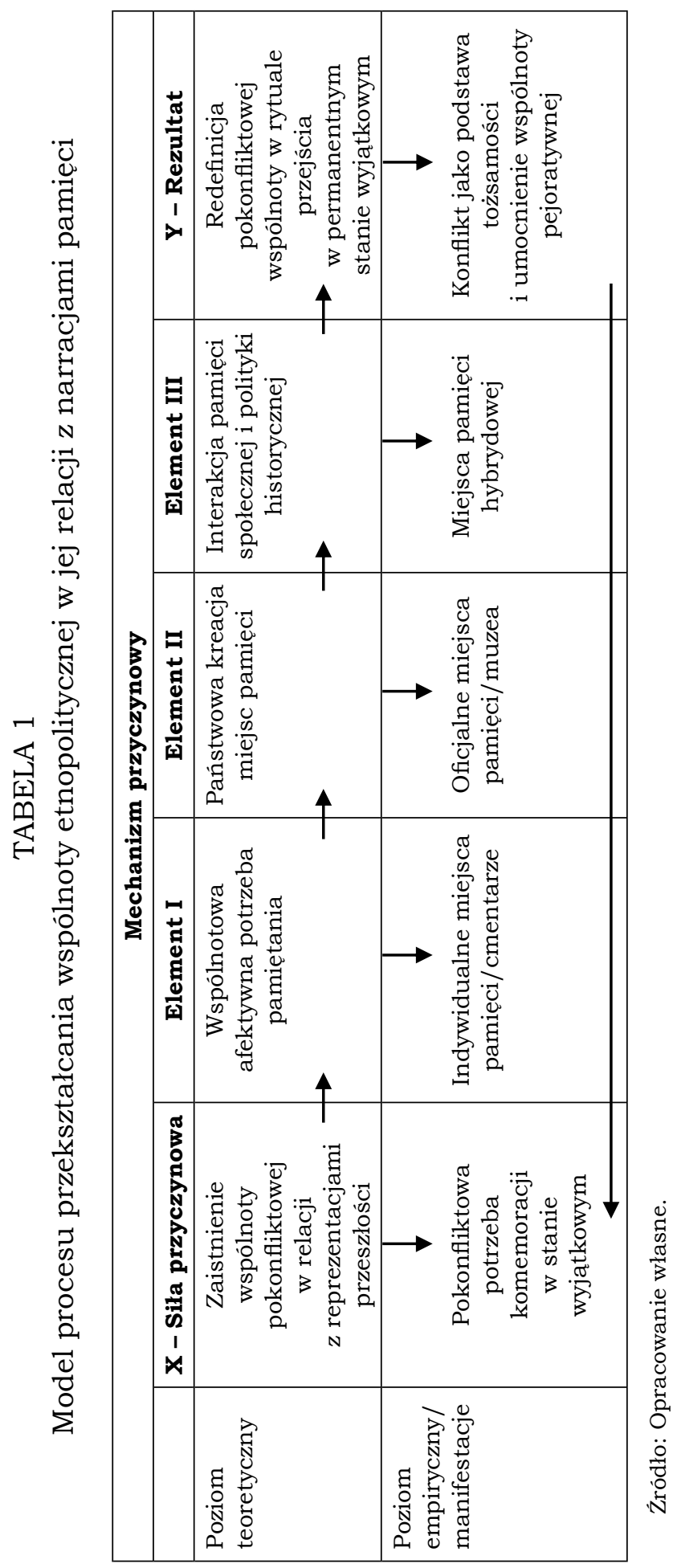


definiowanej wspólnoty narodowej. Jedynie zakończenie stanu wyjątkowego, który w swej esencji jest stanem zawieszenia prawa, może dopuszczać zakończenie rytuału ${ }^{43}$. Konflikt sprawia jednak, że zniesienie stanu wyjątkowego wiązałoby się $z$ całkowitym unicestwieniem wspólnoty i jej sieci symbolicznej Nie ma tu znaczenia, jak miałoby wyglądać zakończenie stanu wyjątkowego, a więc istnienia nieuznawanego zależnego quasi-państwa de facto niepodległego. Nieistotne jest, czy Górski Karabach stanie się częścią Armenii, czy też zostanie ponownie włączony pod jurysdykcję Azerbejdżanu lub też istnieć będzie jako terytorium koncyliacyjnie zarządzane wspólnie przez Baku i Erywań. Obecnie nierealnym scenariuszem jest uznanie Górskiego Karabachu na arenie międzynarodowej i uzyskanie przez niego niezależności politycznej. Tylko takie rozwiązanie toczącego się konfliktu mogłoby zapewnić przetrwanie wspólnocie Ormian karabachskich w obecnym kształcie. Trwanie wspólnoty w permanentnym stanie wyjątkowym sprawia, że może ona bazować jedynie na konflikcie, jeśli ma być odmienna od wspólnoty wszystkich Ormian. W konsekwencji definiowana jest $\mathrm{w}$ odniesieniu do antagonistycznej postawy wobec tych, dla których w Górskim Karabachu nie ma miejsca po zakończeniu zbrojnej fazy konfliktu. Zlewanie się różnych porządków pamięci uniemożliwia budowanie pozytywnego odniesienia dla tych, którzy kategoryzowani sa jako Inni. Czas upływający od wyznaczającej początek wspólnoty cezury czasowej zaciera pozytywne aspekty wspólnej przeszłości, powodując coraz trudniejsze wyobrażanie pozytywnego zakończenia dziwnej wojny. Wspólnota tak głęboko powiązana $z$ konfliktem samym w sobie, ze stanem wyjątkowym, nie może istnieć bez niego.

${ }^{43}$ W Górskim Karabachu istnieje oczekiwanie na poziomie społeczeństwa obywatelskiego rozwiazania konfliktu, które stoi w jawnej opozycji nie tylko do propozycji międzynarodowych i azerbejdżańskich, ale także do oficjalnego stanowiska Armenii. Te środowiska najczęściej wspierają utrzymanie modelu wspólnoty już ukształtowanego, który miałby zostać usankcjonowany i zalegalizowany międzynarodowo. Zob.: V. Kopecek et al., Conflict Transformation..., s. 455-457. 